MARINA MERKAŠ

Hrvatsko katoličko sveučilište, Odjel za psihologiju marina.merkas@unicath.hr
Primljeno: 09. 10. 2019.

Prihvaćeno: 16. 10. 2019.

DOI: $10.21857 / y v j r d c q w 0 y$

\title{
POVEZANOST EKONOMSKOG PRITISKA IZ PERSPEKTIVE RODITELJA I DJECE S DOBROBITI DJECE
}

Radom se ispituje povezanost dječjeg i roditeljskog doživljaja ekonomskog pritiska s dobrobiti djece. Hipoteza o doprinosu dječjeg i roditeljskog doživljaja ekonomskog pritiska objašnjenju razine nade, samopoštovanja i zadovoljstva životom djece testira se na uzorku djece u adolescenciji $i$ njihovih roditelja koji su sudjelovali u kratkotrajnom, longitudinalnom istraživanju s dvije točke mjerenja u okviru znanstvenog projekta "Rad roditelja, ekonomske teškoće obitelji i dobrobit roditelja i djece". Rezultati su pokazali da dječji doživljaj većeg ekonomskog pritiska značajno pridonosi nižim razinama nade, samopoštovanja i zadovoljstva životom djece, a roditeljski doživljaj većeg ekonomskog pritiska nižem zadovoljstvu životom u djece.

\section{UVOD}

Istraživanja su pokazala kako je socioekonomski status (SES) obitelji važna odrednica razvojnih ishoda u djece različite dobi (npr. Bradley i Corwyn, 2002; McLoyd, 1998), no u literaturi se navodi da su, u usporedbi sa SES-om obitelji, ekonomske teškoće, pritisak i prilagodba snažnije povezane s različitim razvojnim ishodima u djece različite dobi (npr. Agnew, Matthews, Bucher, Welcher i 
Keyes, 2008; Conger, Conger i Martin, 2010; Yoshikawa, Aber i Beardslee, 2012). ${ }^{1}$ Ekonomske teškoće djeluju na prilagodbu i dobrobit djeteta kroz različite obiteljske procese i varijable, poput roditeljskog ponašanja, sukoba među roditeljima i roditeljskih poteškoća u funkcioniranju (npr. depresivnost) (npr. Conger i sur., 2010; McLoyd, 1990; Yoshikawa i sur., 2012). Procesi djelovanja ekonomskih teškoća i pritiska na razini djeteta, odnosno putem učinaka na dijete, za sada su samo teorijski opisani u literaturi (npr. Yoshikawa i sur., 2012), no empirijski neistraženi, s rijetkim izuzetcima (npr. Mistry, Benner, Tan i Kim, 2009; Wadsworth i Compas, 2002). Stoga, svrha ovog rada je empirijski provjeriti u kojoj mjeri dječji doživljaj ekonomskog pritiska, uz prisutnost roditeljskog doživljaja ekonomskog pritiska, pridonosi objašnjenju dobrobiti djece u razdoblju adolescencije.

Nepovoljno djelovanje ekonomskog stresa na dobrobit djece različite dobi istraživano je ponajviše u okviru modela (ekonomskog) obiteljskog stresa (npr. Ajduković i Rajter, 2014; Conger i sur., 1992; Conger i sur., 2010; Conger, Ge, Elder, Lorenz i Simons, 1994; Rajhvajn Bulat i Ajduković, 2012; Rajter, 2013). Prema proširenom modelu obiteljskog stresa na život djece (eng. Extension of the family stress model to the lives of children), ekonomske teškoće utječu na život djece primarno kroz utjecaj na život i funkcioniranje njihovih roditelja (Conger i sur., 2010). Ekonomske teškoće (npr., nizak prihod, visok udjel duga u odnosu na imovinu i prihode) i pritisak (npr., nezadovoljene materijalnih potreba u obitelji, nemogućnost plaćanja računa) koje roditelji doživljavaju povezani su s njihovim ponašanjem prema djeci, odnosno sklonosti korištenju nedosljednih obrazaca roditeljske prakse, neuključenosti i nasilnog ponašanja prema djeci. Modelom se predviđa da roditeljstvo posreduje u odnosu roditeljske uznemirenosti i bračnih sukoba (nastalih uslijed ekonomskih teškoća i pritisaka) i razvoja djeteta na način da smanjuje kompetentno funkcioniranje djeteta i povećava prisutnost internaliziranih i eksternaliziranih problema u djece.

U literaturi se negativan učinak niskog SES-a i ekonomskih teškoća obitelji na razvoj i dobrobit djece objašnjava kroz ograničenja ili nedostatak resursa potrebnih za optimalan, zdrav i pozitivan razvoj (npr. roditeljsko ulaganje) te psihosocijalne utjecaje (npr., neadekvatni roditeljski odgojni postupci) (Bradley i Corwyn, 2002). Iz perspektive resursa, obitelji s višim ekonomskim resursima mogu značajno uložiti u razvoj djeteta, dok obitelji u nepovoljnoj ekonomskoj situaciji moraju ulagati u neposredne obiteljske potrebe (npr., plaćanje računa).

Napomena: Rad je izrađen na temelju podataka prikupljenih u znanstvenom projektu „Rad roditelja, ekonomske teškoće obitelji i dobrobit roditelja i djece“ (HKS-2016-3) Hrvatskog katoličkog sveučilišta. Zahvaljujem se djeci, roditeljima, stručnim suradnicima i nastavnicima u školama te ravnateljima škola na sudjelovanju u projektu. 
Ulaganje u djecu uključuje nekoliko dimenzija: a) roditeljsko izravno i neizravno, kroz plaćene instrukcije i dodatno obrazovanje, poticanja učenja, b) opskrbljivanje adekvatnom hranom, odjećom, obućom i zdravstvenom zaštitom i c) život u ekonomski sigurnijoj, stabilnijoj i bogatijoj okolini koja potiče dječji pozitivan razvoj. Stoga, bolje obrazovani roditelji koji rade na bolje plaćenim i prestižnijim poslovima moći će više ulagati u obrazovanje i zdravlje svog djeteta. Iz perspektive psihosocijalnih utjecaja, povezanost niskog SES-a i ekonomskih teškoća $s$ nepovoljnim razvojnim ishodima uglavnom se objašnjava sniženim roditeljskim kompetencijama i neadekvatnim roditeljskim odgojnim postupcima uslijed ekonomskog pritiska. Modelom ulaganja bolje se mogu objasniti kognitivni ishodi u djece zbog roditeljskog ulaganja, a proširenim modelom obiteljskog stresa na život djece (Conger i sur., 2010) javljanje problema u ponašanju i emocionalnih problema kod djece zbog neprikladne roditeljske prakse.

Osnovne postavke modela (ekonomskoga) obiteljskog stresa replicirane su u različitim uzorcima i to najčešće korištenjem roditeljskih procjena ekonomskih teškoća i pritiska (npr. Benner i Kim, 2010, Conger i sur., 1992; Conger i sur., 1994; Conger i sur., 2002; Elder, Conger, Foster i Ardelt, 1992; Landers-Potts i sur., 2015; Mistry, Vandewater, Huston i McLoyd, 2002; Parke i sur., 2004; Skinner, Elder i Conger, 1992; Solantaus, Leinonen i Punamäki, 2004; Yeung, Linver i Brooks-Gunn, 2002). Empirijska istraživanja su pokazala da je doživljaj obiteljskog ekonomskog pritiska, odnosno stresa, uzrokovanog ekonomskim teškoćama povezan s internaliziram (npr., depresivnost, anksioznost) i eksternaliziranim (npr., agresivno ponašanje) problemima i akademskim ishodima (npr., niže školske ocjene) u djece različite dobi (npr. Bolger, Patterson, Thompson i Kupersmidt, 1995; DeCarlo Santiago, Wadsworth i Stump, 2011; Landers-Potts i sur., 2015; Mistry i sur., 2009; Wadsworth i Compas, 2002; Shek, 2003, 2005) te smanjenom psihološkom dobrobiti adolescenata (npr. Evans i English, 2002; Wadsworth i sur., 2008). Dosadašnja istraživanja većinom su bila usmjerena na ispitivanje doprinosa ekonomskih teškoća javljanju problema u ponašanju i emocionalnih problema djece, a manje su se istraživali učinci koje ekonomske teškoće i pritisak imaju na dobrobit i pozitivne razvojne ishode u djece. Kako bi se dobila cjelovitija slika povezanosti ekonomskih teškoća i pritiska s funkcioniranjem djece, potrebno je ispitati i pozitivne razvojne ishode u djece.

Oslanjanje samo na roditeljske izvještaje o ekonomskim teškoćama i pritisku je dovelo do previda i zanemarivanja važnosti dječjeg doživljaja ekonomskih teškoća s kojima se obitelj suočava za razvoj i dobrobit djece. lako, u literaturi se mogu naći izuzetci. Na primjer, Mistry i njezini suradnici (2009) su pokazali kako je učinak roditeljskog doživljaja ekonomskog stresa na postignuće, školsku uklju- 
čenost i pozitivne stavove o obrazovanju adolescenata posredovan adolescentskom percepcijom ekonomskih ograničenja i prisutnosti depresivnih simptoma u adolescenata. Wadsworth i Compas (2002) su pokazale da je adolescentsko iskustvo ekonomskih ograničenja izravno i neizravno, kroz obiteljske sukobe i niz strategija suočavanja s ekonomskim ograničenjima, povezano s problemima u prilagodbi (npr., anksioznost, depresivnost). Izravan učinak dječjeg doživljaja obiteljskih ekonomskih teškoća na funkcioniranje djece nije teorijski opisan u literaturi, iako neki empirijski nalazi iz literature ukazuju na njegovo postojanje (npr. Lempers, Clark-Lempers i Simons, 1989; Wadsworth i Compas, 2002). Hipoteza o tome bi li dječji doživljaj ekonomskog pritiska izravno pridonosio dječjem razvoju da se u jednom modelu ispitaju svi pretpostavljeni medijatori (npr., roditeljstvo, bračni sukobi), već je postavljena i raspravljana u literaturi (Conger i sur., 2010). S obzirom da su potrebne spoznaje o dječjem procesiranju i doživljavanju obiteljskih ekonomskih teškoća i pritiska te o tome kako to pridonosi dobrobiti djece u različitim kulturama i uzorcima (Mistry i sur., 2009), u ovom radu bavit ćemo se dječjim doživljajem ekonomskog pritiska. Posebno je to važno ispitati u djece tijekom adolescencije, jer su ona kognitivno sposobna objektivnije obraditi informacije o SES-u obitelji u odnosu na djecu mlađe dobi te jasno iskazati svoje doživljaje i misli o ekonomskim teškoćama i prilagodbi obitelji. Uz to, rezultati malobrojnih istraživanja ukazuju na različit doživljaj ekonomskog stresa kod roditelja i njihove djece, pri čemu roditelji doživljavaju više razine trenutnog ekonomskog stresa i veću zabrinutost oko buduće ekonomske situacije (Shek, 2003).

Novija istraživanja pokazuju kako iskustvo obiteljskog ekonomskog pritiska koje doživljavaju djeca koja su u razvojnom razdoblju adolescencije ima izravan učinak na njihovo funkcioniranje, dok su u ranijim istraživanjima ispitivani samo neizravni učinci preko roditeljskog psihološkog zdravlja i roditeljskih odgojnih postupaka (npr. Wadsworth i sur., 2008). S obzirom na važnost i nedovoljnu istraženost doživljaja ekonomskog pritiska iz perspektive djece, posebice djece koja su u razdoblju adolescencije u Hrvatskoj, u ovom smo se radu usmjerili na dječji doživljaj ekonomskog pritiska i njegov odnos s pokazateljima dobrobiti djece u adolescenciji. Svrha rada je ispitati doprinos dječjeg i roditeljskog doživljaja ekonomskog pritiska dobrobiti djece u razdoblju adolescencije. Odnosno, ispituje se pridonosi li dječji doživljaj ekonomskog pritiska, uz roditeljski doživljaj ekonomskog pritiska te kontrolu obiteljskih prihoda i obrazovanja roditelja, objašnjenju tri pokazatelja dobrobiti u djece - nade, samopoštovanja i zadovoljstva životom. Koristeći podatke dobivene od djece i roditelja iz kratkotrajnog longitudinalnog istraživanja želi se provjeriti hipoteza o negativnom doprinosu ekonomskog pritiska iz perspektive djece njihovoj dobrobiti. Stoga, očekuje se da izraženi eko- 
nomski pritisak koji doživljavaju djeca značajno i izravno pridonosi objašnjenju nižih razina nade, samopoštovanje i zadovoljstva životom, bez obzira na doprinos roditeljskog doživljaja ekonomskog pritiska, prihoda obitelji i stupnja obrazovanja roditelja.

\section{METODA}

\section{Sudionici}

Rad se temelji na podatcima prikupljenim u okviru znanstvenog projekta „Rad roditelja, ekonomske teškoće obitelji i dobrobit roditelja i djece“ Hrvatskog katoličkog sveučilišta. U istraživanju s dvije točke mjerenja za potrebe projekta sudjelovalo je 348 djece iz sedam osnovnih (6., 7. i 8. razred) i četiri srednje (1., 2. i 3. razred) škole s područja Grada Zagreba i Zagrebačke županije. U ovom radu, s obzirom na istraživačka pitanja, koristi se uzorak od 285 djece $(38,2 \%$ dječaka), koja žive s oba roditelja i koja su zajedno s roditeljima sudjelovali u obje točke mjerenja. Prosječna dob djece je 15 godina $(M=15,21, S D=1,76)$. Prosječna dob očeva u prvom mjerenju (T1) je 47 godina $(S D=5,78)$, a majki 44 godine $(S D=5,17)$. Većina očeva ima završenu srednju školu $(58,5 \%)$, manji udio njih ima završen fakultet ili viši stupanj obrazovanja $(27,1 \%)$, a najmanji udio očeva ima završenu višu školu $(11,3 \%)$ te nezavršenu ili završenu osnovnu školu (3,2\%). Većina očeva je u T1 bila zaposlena $(88,2 \%)$, dok manji udio njih nije bio zaposlen (3,8\%) ili je u mirovini (8\%). Većina majki ima završenu srednju školu $(56,7 \%)$, manji udio njih ima završen fakultet ili viši stupanj obrazovanja (31,1\%), a najmanji udio majki u uzorku ima završenu višu školu $(8,5 \%)$ te nezavršenu ili završnu osnovnu školu (3,7\%). Većina majki je u T1 bila zaposlena (85\%), dok manji udio nije bio zaposlen $(13,5 \%)$ ili je u mirovini $(1,5 \%)$.

\section{Varijable i način operacionalizacije}

\section{Nada}

Kao pokazatelj nade u djece korišteni su odgovori djece iz drugog mjerenja (T2) na Skali nade za djecu (eng. Children's Hope Scale; Snyder i sur., 1997), koja se sastoji od dvije podskale: misli o putovima do cilja (eng. pathways; npr. „Kada imam problem, mogu smisliti mnogo načina kako ga riješiti.") i misli o vlastitim sposobnostima za primjenu tih putova (eng. agency; npr. „Ide mi jednako dobro kao mojim vršnjacima."). Svaka podskala sastoji se od tri čestice na koje se odgovara na skali od šest stupnjeva ( 1 = „nikada”, $6=$ „uvijek”). Analizom glavnih komponenata potvrđeno je postojanje jednog faktora koji objašnjava 53,33\% 
varijance. Pouzdanost skale iznosi Cronbach $\alpha=0,84$. Ukupan rezultat izračunan je kao prosjek odgovora na svih šest čestica, a viši rezultat ukazuje na višu razinu nade $u$ djece.

\section{Samopoštovanje}

Kao pokazatelj samopoštovanja u djece korišteni su odgovori djece iz T2 na kratkoj verziji Rosenbergove skale samopoštovanja (eng. Rosenberg Self-Esteem Scale; Rosenberg, Schooler i Schoenbach, 1989), koja se sastoji od šest čestica (npr. „Osjećam da vrijedim barem koliko i drugi.”) i ispituje opće samopoštovanje. Djeca su odgovarala na skali od četiri stupnja ( 1 = „uopće se ne slažem”, 4 = „potpuno se slažem”). Analizom glavnih komponenata potvrđen je jedan faktor koji je objasnio ukupno 51,6\% varijance. Pouzdanost skale iznosi Cronbach $\alpha=$ 0,81 . Ukupan rezultat izračunan je kao prosjek odgovora na svim česticama, a viši rezultat ukazuje na veće samopoštovanje u djece.

\section{Zadovoljstvo životom}

Kao pokazatelj zadovoljstva životom u djece, korišteni su odgovori djece iz T2 na pet čestica Kratke multidimenzionalne skale zadovoljstva životom za djecu (eng. Brief Multidimensional Students' Life Satisfaction Scale; Selingson, Huebner i Valois, 2003) kojim se ispituje zadovoljstvo raznim područjima života (zadovoljstvo obitelji, prijateljstvom, školom, samim sobom i mjestom života; npr. „Koliko si općenito zadovoljan svojim iskustvima u obitelji?”) na skali za odgovore od 1 („potpuno sam nezadovoljan”) do 7 („potpuno sam zadovoljan”). Analiza glavnih komponenata pet čestica pokazala je postojanje jednog faktora koji je objasnio ukupno 50,26\% varijance. Pouzdanost skale iznosi Cronbach $\alpha=0,75$. Ukupan rezultat izračunan je kao prosjek odgovora na pet čestica, pri čemu viši rezultat znači veće globalno zadovoljstvo životom u djece.

\section{Ekonomski pritisak}

U ovom radu korištena su dva pokazatelja - dječji i roditeljski doživljaj ekonomskog pritiska.

Kao pokazatelj dječjeg doživljaja ekonomskog pritiska ili stresa, korišteno je osam čestica koje mjere ekonomska ograničenja iz Upitnika odgovora na stres (eng. Responses to Stress Questionnaire - RSQ; Wadsworth i Compas, 2002). Osam čestica originalno su preuzete iz rada Congera i suradnika (1994) u kojemu se ispitivao obiteljski ekonomski pritisak te su prilagođene ispitivanju iskustva 
adolescenata o ekonomskom pritisku koji doživljavaju u obitelji. U ovom radu koriste se odgovori djece iz T1 o učestalosti javljanja ekonomskih ograničenja u obitelji u proteklih šest mjeseci (npr. "Moji roditelji nisu imali dovoljno novca da plate račune.") na skali od četiri stupnja ( $0=$ „nikad se nije događalo”, $3=$ „uvijek se događalo"). Analizom glavnih komponenata svih čestica na korištenom uzorku utvrđen je jedan faktor kojim je objašnjeno ukupno 56,45\% varijance. Pouzdanost ukupnog rezultata iznosi Cronbach $\alpha=0,88$. U ovom radu viši rezultat, izračunat kao prosjek osam čestica, ukazuje na višu procjenu ekonomskog pritiska u obitelji.

Kao pokazatelj roditeljskog doživljaja ekonomskog pritiska, u ovom radu korišteni su odgovori roditelja iz T1 na pet čestica koje su preuzete iz rada RabotegŠarić, Pećnik i Josipović (2003), a odnose se na pokazatelje uštede na troškovima za dijete („Niste mogli djeci kupiti odjeću kakvu su htjela.”, „Niste mogli djeci kupiti hranu kakvu su htjela.”, „Niste mogli djeci dati džeparac.”, „Niste mogli djeci platiti putovanje na školske izlete.”, „Niste mogli djeci platiti sudjelovanje u slobodnim aktivnostima."). Roditelji su odgovarali s „da” ili „ne” ovisno o prisutnosti određene teškoće u podmirivanju troškova za dijete (raspon rezultata je od 0 do 5). Ukupni rezultat izračunan je kao prosjek odgovora majki i očeva na pet čestica, a viši rezultat ukazuje na izraženiji ekonomski pritisak u području podmirivanju troškova za dijete u obitelji.

\section{Sociodemografske varijable}

$\mathrm{U}$ radu se koriste odgovori oba roditelja iz T1 na pitanje o obrazovanju roditelja (a) nezavršena ili završena osnovna škola; (b) završena srednja škola; (c) završena viša škola; (d) završen fakultet; (e) magisterij ili doktorat znanosti) i roditeljskoj procijeni prosječnog mjesečnog prihoda po članu kućanstva (a) manje od 1.500,00 kn; (b) od 1.501,00 do 2.500,00 kn;(c) od 2.501,00 kn do 3.500,00 kn; (d) od 3.501,00 do 4.500,00 kn; (e) od 4.501,00 do 5.500,00 kn;(f) više od $5.501,00$ kn). U analizi rezultata, majčina i očeva procjena prosječnog mjesečnog prihoda po članu kućanstva je uprosječena u jedan pokazatelj procjene mjesečnog prihoda po članu kućanstva te se u rezultatima koristi kao pokazatelj prihoda obitelji, a viši rezultat ukazuje na veće prihode.

\section{Postupak}

$\mathrm{U}$ radu se koriste podatci prikupljeni u kratkotrajnom longitudinalnom istraživanju koje je provedeno u okviru znanstvenoga projekta "Rad roditelja, ekonomske teškoće obitelji i dobrobit roditelja i djece" (HKS-2016-3), financira- 
nog od Hrvatskog katoličkog sveučilišta, uz odobrenje Etičkoga povjerenstva Hrvatskoga katoličkog sveučilišta i dopuštenje Ministarstva znanosti, obrazovanja i sporta. Podatci su prikupljeni tijekom 2016. godine. Dopuštenje za provedbu istraživanja u pojedinim školama dobiveno je od ravnatelja škola te je provedeno uz pomoć stručnih suradnika u školama. Učenicima su u školi podijeljeni obrasci koje su trebali potpisati njihovi roditelji ili skrbnici i oni sami ako su suglasni sa sudjelovanjem u istraživanju te upitnici za roditelje koje su roditelji popunili kod kuće te potom dali djeci da ih u zalijepljenoj omotnici donesu natrag u školu. U istraživanje su uključeni samo učenici za koje su roditelji dali suglasnost i koji su sami pristali sudjelovati u projektu (16\% kontaktiranih). Roditelji su upitnike popunili kod kuće, a djeca su upitnike popunila u školi tijekom jednog školskog sata te su njihovi odgovori upareni pomoću zaporki koje su upisali na upitnike. Kao zahvalu za sudjelovanje u istraživanju, učenici su dobili simbolične nagrade (male bilježnice).

\section{REZULTATI}

Rezultati pokazuju kako su djeca u prosjeku zadovoljna svojim životom te u prosjeku izvještavaju o višim razinama samopoštovanja i nade u odnosu na korištene skale za odgovore u T2 (Tablica 1.) Djeca i roditelji u prosjeku procjenjuju ekonomski pritisak niskim u T1 (Tablica 1.). Prema odgovorima roditelja o doživIjenom ekonomskom pritisku u području troškova za dijete najčešće se događalo da djeci nisu mogli kupiti odjeću kakvu su htjela $(39,1 \%)$, zatim dati im džeparac $(16,9 \%)$, platiti sudjelovanje djece u školskim izletima (14\%), kupiti hranu kakvu su željela $(10,7 \%)$ te najrjeđe platiti putovanja na školske izlete $(5,8 \%)$.

Rezultati pokazuju kako su dječji i roditeljski doživljaj ekonomskog pritiska značajno i pozitivno povezani u T1 (Tablica 1.). Dječji doživljaj ekonomskog pritiska u T1 značajno je i negativno povezan s nadom, samopoštovanjem i zadovoljstvom životom djece u T2 te prihodima obitelji (T1) i stupnjem obrazovanja roditelja. Roditeljske procjene ekonomskog pritiska u području podmirivanja troškova za djecu u T1 značajno su i negativno povezane s nadom i zadovoljstvom životom djece u T2 te prihodima obitelji (T1) i stupnjem obrazovanja roditelja. Nada, samopoštovanje i zadovoljstvo životom djece su međusobno pozitivno i značajno povezani. Stupanj obrazovanja roditelja značajno je i pozitivno povezan s prihodima obitelji (Tablica 1.).

Kako bi se utvrdio doprinos dječjeg i roditeljskog doživljaja ekonomskog pritiska iz T1 objašnjenju samopoštovanja, nade i zadovoljstva životom djece iz T2, provedene su tri hijerarhijske regresijske analize (Tablica 2.). Tri kriterijske vari- 
jable bile su nada, samopoštovanje i zadovoljstvo životom iz T2. U svakoj analizi u prvom koraku uvedene su obrazovanje oba roditelja i prihodi obitelji kao prediktori, a u drugom koraku kao prediktori uvedeni su dječji i roditeljski doživljaj ekonomskog pritiska iz T1.

Tablica 1. Aritmetičke sredine i standardne devijacije ispitivanih varijabli te povezanosti među varijablama u radu

\begin{tabular}{|c|c|c|c|c|c|c|c|c|c|}
\hline & $M$ & SD & 1. & 2. & 3. & 4. & 5. & 6. & 7. \\
\hline $\begin{array}{l}\text { 1. Ekonomski } \\
\text { pritisak - D (T1, } \\
\text { D) }\end{array}$ & 0,36 & 0,48 & 1 & & & & & & \\
\hline $\begin{array}{l}\text { 2. Ekonomski } \\
\text { pritisak - M-O } \\
\text { (T1) }\end{array}$ & 0,59 & 0,94 & $0,457 * *$ & 1 & & & & & \\
\hline $\begin{array}{l}3 . \\
\text { Samopoštovanje } \\
\text { - D (T2) }\end{array}$ & 3,27 & 0,51 & $-0,229 * *$ & $-0,117$ & 1 & & & & \\
\hline $\begin{array}{l}\text { 4. Zadovoljstvo } \\
\text { životom - D (T2) }\end{array}$ & 5,74 & 0,90 & $-0,385^{*} *$ & $-0,314 * *$ & $0,634 * *$ & 1 & & & \\
\hline 5. Nada - D (T2) & 4,36 & 0,89 & $-0,209 * *$ & $-0,170 *$ & $0,638 * *$ & $0,564 * *$ & 1 & & \\
\hline $\begin{array}{l}\text { 6. Prihodi obitelji } \\
-\mathrm{M}-\mathrm{O}(\mathrm{T} 1)\end{array}$ & - & - & $-0,305^{* *}$ & $-0,392 * *$ & 0,105 & 0,115 & 0,116 & 1 & \\
\hline $\begin{array}{l}\text { 7. Obrazovanje } \\
\text { oca (T1) }\end{array}$ & - & - & $-0,147^{*}$ & $-0,145^{*}$ & 0,048 & $-0,017$ & 0,017 & $0,239 * *$ & 1 \\
\hline $\begin{array}{l}\text { 8. Obrazovanje } \\
\text { majke (T1) }\end{array}$ & - & - & $-0,159 * *$ & $-0,264 * *$ & 0,084 & 0,131 & 0,018 & $0,408 * *$ & $0,439 * *$ \\
\hline
\end{tabular}

Napomena. ${ }^{*} p<0,05,{ }^{* *} p<0,01 ; \mathrm{T} 1$ - prvo mjerenje, T2 - drugo mjerenje, D - dijete, M-O uprosječeni odgovori majke i oca. 
MARINA MERKAŠ: Povezanost ekonomskog pritiska iz perspektive roditelja i djece s dobrobiti djece

Tablica 2. Rezultati hijerarhijskih regresijskih analiza s prihodima obitelji, obrazovanjem roditelja i ekonomskim pritiskom kao prediktorima samopoštovanje, zadovoljstva životom i nade djece

\begin{tabular}{|l|c|c|c|}
\hline & $\begin{array}{c}\text { Samopoštovanje - D } \\
(\mathrm{T} 2)\end{array}$ & $\begin{array}{c}\text { Zadovoljstvo } \\
\text { životom - D (T2) }\end{array}$ & Nada - D (T2) \\
\hline 1. korak & $\beta$ & $\beta$ & $\beta$ \\
\hline Obrazovanje oca (T1) & 0,064 & $-0,021$ & 0,022 \\
\hline Obrazovanje majke (T1) & 0,026 & 0,103 & 0,065 \\
\hline Prihodi obitelji - M-O (T1) & 0,063 & 0,069 & 0,052 \\
\hline & $\mathrm{R}^{2}=0,014$ & $\mathrm{R}^{2}=0,019$ & $\mathrm{R}^{2}=0,012$ \\
\hline & $\mathrm{p}=0,513$ & $\mathrm{p}=0,370$ & $\mathrm{p}=0,569$ \\
\hline 2. korak & $\beta$ & $\beta$ & $\beta$ \\
\hline Ekonomski pritisak-D (T1) & $-0,289^{* *}$ & $-0,322^{* *}$ & $-0,245^{* *}$ \\
\hline Ekonomski pritisak-M-O (T1) & 0,043 & $-0,190^{*}$ & $-0,047$ \\
\hline & $\mathrm{R}^{2}=0,082$ & $\mathrm{R}^{2}=0,189$ & $\mathrm{R}^{2}=0,077$ \\
\hline & $\Delta \mathrm{R}=0,068$ & $\Delta R=0,169$ & $\Delta R=0,064$ \\
\hline & $\mathrm{p}=0,017$ & $\mathrm{p}=0,000$ & $\mathrm{p}=0,023$ \\
\hline
\end{tabular}

Napomena. $* p<0,05, * * p<0,01 ; \mathrm{T} 1$ - prvo mjerenje, $\mathrm{T} 2$ - drugo mjerenje, $\mathrm{D}$ - dijete, $\mathrm{M}-\mathrm{O}$ - uprosječeni odgovori majke i oca.

Rezultati provedene regresijske analize sa samopoštovanjem kao kriterijem pokazuju da je na temelju obrazovanja roditelja, prihoda obitelji te dječjeg i roditeljskog doživljaja ekonomskog pritiska moguće objasniti 8,2\% ukupne varijance samopoštovanja (Tablica 2.). Kao jedini značajni prediktor samopoštovanja djece u T2 pokazale su se dječje procjene ekonomskog pritiska iz T1 (Tablica 2.), pri čemu djeca koja ekonomski pritisak procjenjuju višim u T1 svoje samopoštovanje procjenjuju nižim u T2. Regresijska analiza sa zadovoljstvom životom kao kriterijem pokazala je kako je na temelju seta prediktora moguće objasniti 18,9\% varijance zadovoljstva životom djece (Tablica 2.). Značajni prediktori zadovoljstva životom djece u T2 su dječja i roditeljska procjena ekonomskog pritiska iz T1, odnosno djeca koja su ekonomski pritisak obitelji procijenili većim u T1 i čiji su roditelji ekonomski pritisak procijenili višim u T1 imala su niže zadovoljstvo životom u T2. Treća regresijska analiza s nadom djece kao kriterijem pokazala je kako je na temelju seta prediktora moguće objasniti 7,7\% varijance nade, pri čemu je jedini značajan prediktor bio ekonomski pritisak iz perspektive djece izmjeren u T1. Djeca koja su doživjela veći ekonomskim pritisak u T1 imaju nižu nadu u T2. Općenito se na temelju rezultata može zaključiti kako obrazovanje roditelja i prihodi obitelji ne pridonose izravno i značajno razini nade, samopoštovanja i 
zadovoljstva životom djece u adolescenciji te da ekonomski pritisak objašnjava mali, ali značajan dio varijance tri kriterija.

Dodatno je provjereno mijenja li se značajnost prediktora ekonomski pritisak uvođenjem varijable spol djeteta u analizu jer je iz literature poznato da postoje značajne razlike između djevojčica i dječaka u nekim od istraživanih konstrukata (npr. Berk, 2008). S obzirom da se pokazalo kako postoje značaje razlike između djevojčica i dječaka u nadi ( $t(208)=2,64, p=0,009)$, samopoštovanju ( $t$ (205) $=3,17, p=0,002)$ i zadovoljstvu životom $(t(203)=3,48, p=0,001)$, pri čemu su dječaci u prosjeku postizali više rezultate na sve tri kriterijske varijable, ponovno su provedene tri regresijske analize s tim da je u prvom koraku u analizu uvedena i varijabla spol djeteta. Rezultati tih analiza sukladni su rezultatima analiza prikazanih u Tablici 2. s obzirom na značajnosti prediktorskih varijabli dječjeg i roditeljskog doživljaja ekonomskog pritiska, prihoda obitelji i obrazovanja roditelja. Spol djeteta pokazao se značajnim prediktorom u sve tri regresijske analize, pri čemu je muški spol bio povezan s višim razinama samopoštovanja, zadovoljstva životom i nade. U ovom radu razmatrat će se odnosi između istraživanih konstrukata na cijelom uzorku (Tablica 2.), jer nisu utvrđene značajne razlike u dječjem i roditeljskom doživljaju ekonomskog pritiska te prihodima obitelji i obrazovanju roditelja s obzirom na spol djeteta, a rezultati regresijskih analize s obzirom na prediktorsku vrijednost ekonomskog pritiska u objašnjenju dobrobiti djece se ne mijenjaju uvođenjem varijable spola djeteta u analizu te spolne razlike nisu od središnjeg interesa rada.

\section{RASPRAVA}

Cilj rada bio je ispitati pridonosi li dječji doživljaj ekonomskog pritiska, zajedno s roditeljskim doživljaj ekonomskog pritiska, uz kontrolu obiteljskih prihoda i obrazovanja roditelja, objašnjenju nade, samopoštovanja i zadovoljstva životom djece u razdoblju adolescencije. Rezultati rada potvrdili su hipotezu o negativnom doprinosu ekonomskog pritiska iz perspektive djece i njihovih roditelja objašnjenju razine dobrobiti djece. Ekonomski pritisak koji doživljavaju djeca značajan je i negativan prediktor nade, samopoštovanja i zadovoljstva životom djece. Roditeljski doživljaj ekonomskog pritiska značajan je i negativan prediktor zadovoljstva životom djece. Rezultati rada repliciraju nalaz o povezanosti ekonomskog pritiska iz perspektive roditelja s dobrobiti djece, ali repliciraju i nalaze rijetkih istraživanja o izravnom doprinosu dječjeg doživljaja ekonomskih teškoća i pritiska dobrobiti djece (npr. Wadsworth i Compas, 2002). Općenito nalazi rada ukazuju na važan i značajan izravan doprinos percepcije djece o ekonomskim 
uvjetima u kojima odrastaju njihovoj nadi, samopoštovanju i zadovoljstvu životom te ukazuju na potencijalni smjer revidiranja teorijskih okvira za proučavanje učinaka ekonomskih teškoća i pritiska na razvoj djece u adolescenciji.

Dječji veći doživljaj ekonomskog pritiska u T1 pridonosi nižim razinama nade djece u T2. Istraživanja o povezanosti ekonomskih teškoća i pritiska s nadom u djece i odraslih su rijetka (npr. Brdovčak, Merkaš i Šakić Velić, 2018; Mistry, Lowe, Benner i Chien, 2008; Prawitz, Kalkowski i Cohart, 2013), no nalazi ovog rada sukladni su njihovim rezultatima. Brdovčak i suradnice (2018) pokazale su kako su više razine dječjeg doživljaja ekonomskog pritiska pozitivno povezane s nadom djece koristeći transverzalne podatke od djece iz projekta na kojem se temelji i ovaj rad, s tim da se ovim radom potvrđuje taj odnos na longitudinalnim podatcima prikupljeni od djece i njihovih roditelja. Raboteg-Šarić, Merkaš i Majić (2011) su pokazale kako je obiteljski ekonomski stres negativno povezan s nadom adolescenata. Nadalje, pozitivnu povezanost ekonomskog pritisak i niže nade u majki dobili su Mistry i njezini suradnici (2008) te su pokazali kako ekonomski pritisak izravno previđa niže razine nade, više stresa i depresivnih simptoma u majki te neizravno pridonosi funkcioniranju djece (npr., niža autonomija i socijalna kompetencija, više problema u ponašanju). Prawitz i njezini suradnici (2013) su na uzorku odraslih potvrdili značajan i izravan doprinos višeg ekonomskog pritiska nižim razinama nade. Suočavanje s ekonomskim pritiskom za djecu predstavlja nenormativni životni izazov, za većinu njih je to neugodno iskustvo jer je uzrok pritiska koji doživljavaju izvan njihove kontrole te oni nemaju razvijene vještine suočavanja s takvim tipom stresnih situacija. No, s druge strane, unaprijeđene kognitivne sposobnosti u adolescenciji dopuštaju da se doživljaj nemogućnosti suočavanja s takvim pritiskom (jedna domena života) prelije na njihovo planiranje budućih ciljeva i strategija osmišljavanja tih ciljeva (npr., druga domena života). Stoga, moguće je da doživljavanje izraženijeg ekonomskog pritiska s kojim se djeca ne mogu suočiti smanjuje njihovu nadu u buduće uspješno postavljanje i ostvarenje želja i ciljeva.

Djeca koja su ekonomski pritisak doživljavala višim u T1 ujedno su svoje samopoštovanje procjenjivala nižim u T2. Ovaj nalaz sukladan je rezultatima prijašnjih istraživanja (npr. Brdovčak i sur., 2018; Raboteg-Šarić, Brajša-Žganec i Šakić, 2008; Shek, 2003). Brdovčak i suradnice su pokazale isti obrazac povezanosti dječjeg doživljava ekonomskog pritiska i zadovoljstva životom na transverzalnim podatcima djece iz projekta na kojem se temelji i ovaj rad, ali u ovom radu taj je odnos potvrđen na longitudinalnim podatcima djece i njihovih roditelja. Slično, prijašnja istraživanja pokazuju da niži percipirani ekonomski status obitelji predviđa niže zadovoljstvo životom adolescenata (Raboteg-Šarić i sur., 2008) te da je 
ekonomski stres negativno povezan sa samopoštovanjem adolescenata (Shek, 2003). Osjećaj vlastite vrijednosti u djece ima dva izvora - jedan su mišljenja drugih, bliskih i značajnih im osoba o njima samima, a drugi se odnosi na procjenu vlastitih sposobnosti i uspješnosti. S obzirom na konstrukt ekonomskog pritiska koji je mjeren u ovom radu, potrebnim se čini raspraviti mogućnost da djeca imaju osjećaj kako nisu sposobna nositi se s njime i doživljavaju osjećaj neuspjeha, a koji se ogleda u nižim razinama osjećaja vlastite vrijednosti. Uz to, moguće je da uslijed nemogućnosti roditelja da djeci priušte odjeću, obuću i sve druge materijalne stvari koje žele, oni se osjećaju manje vrijednima u usporedbi sa svojim vršnjacima čiji roditelji to mogu učiniti. Naime, socijalne usporedbe u doba adolescencije postaju sve izraženije te su djeca sklona više se uspoređivati sa svojim vršnjacima.

Djeca koja su doživljavala više ekonomskog pritiska i čiji su roditelji doživljavali više ekonomskog pritiska u T1 ujedno su svoje zadovoljstvo životom procjenjivala nižim u T2. Povezanost ekonomskog pritiska i zadovoljstva životom u djece potvrđena je prijašnjim istraživanjima (npr. Brdovčak i sur., 2018; Shek, 2003). Nalazi ovog rada ukazuju da se povišeni ekonomski pritisak izravno odražava u nezadovoljstvu životom djece, što je potvrđeno i nekim prijašnjim istraživanjima (npr. Wadsworth i Compas, 2002). Ekonomski pritisak operacionaliziran je u radu kroz nemogućnost zadržavanja standarda života obitelji i ispunjavanja potreba i želja djece te uštedi na troškovima za djecu. Uštede na troškovima života, odnosno ekonomska ograničenja su jedna od središnjih komponenti obiteljskih iskustava s ekonomskim pritiskom (Elder i sur., 1992), a osjećaj da su nečije mogućnosti ispunjenja očekivanog i neophodnog standarda života ograničene preljeva se u opći osjećaj nezadovoljstva životom. Zbog kognitivnog razvoja, djeca u adolescenciji su posebno osjetljiva na socijalne usporedbe i razlike između bogatih i siromašnih (McLoyd i sur., 2009; Rosenberg i Pearlin, 1978). S obzirom da je izgled jedna od važni odrednica pojma o sebi i zadovoljstva životom u adolescenta, važnim se čini istaknuti podatak kako je većina roditelja doživjela situaciju u kojoj djeci nije mogla kupiti odjeću kakvu su željela $(39,1 \%)$, što se potencijalno prelilo na opće nezadovoljstvo životom.

Rezultate rada potrebno je sagledati u odnosu na ograničenja i nedostatke provedenog istraživanja te podatke na kojima se temelje zaključci. Većina djece i roditelja izvijestila je o niskim razinama ekonomskog pritiska, djeca su u prosjeku izvijestila o višim razinama dobrobiti i uzorak je bio prigodan te je stoga u budućnosti potrebno odnose među proučavanim konstruktima ispitati na uzorcima djece i roditelja koji se suočavaju s izraženijim ekonomskim teškoćama i pritiskom. Odaziv na sudjelovanje u istraživanju je bio relativno nizak, 
što dovodi u pitanje mogućnost generalizacije spoznaja rada. Rezultati rada se većinom odnose na obitelji koje u prosjeku doživljavaju niže razine ekonomskog pritiska. Nadalje, bilo bi važno djecu i roditelje pitati ista pitanja o ekonomskom pritisku kako bi se njihovi odgovori mogli usporediti. Naime, dječje i roditeljske procjene ekonomskog pritiska su značajno i pozitivno, ali umjereno povezane, vjerojatno i jer su korištena ponešto drugačija pitanja za mjerenje ekonomskog pritiska. Posebice se važnim čini u budućim istraživanjima s djecom u razdoblju adolescencije ispitati i njihovu percepciju obiteljske ekonomske situacije jer su oni, u odnosu na djecu niže životne dobi, kognitivno sposobni realnije procijeniti situaciju i sebe. Uz to, procjene ekonomskog pritiska dobivene od adolescenata odražavaju doživljaj samih adolescenata o tome kako obiteljske ekonomske teškoće djeluju na njih.

Imajući na umu teorijski interakcijski model Congera i suradnika (2010), prema kojemu na dobrobit djece izravno djeluje SES njihove obitelji, obiteljska dinamika i osobna obilježja roditelja, ali neizravno i SES njihovih baka i djedova i obiteljska dinamika u njihovu domu, važnim se čini dalje istraživati temu rada. Posebice jer se zaključno može napisati kako dječji doživljaj ekonomskog pritiska izravno i značajno određuje nadu, samopoštovanje i zadovoljstvo životom djece, bez obzira na doprinos obrazovanja roditelja, prihoda obitelji i roditeljskog doživljaja ekonomskog pritiska. Nalazi rada ukazuju na to da bi se u teorijske modele i okvire za proučavanje učinaka ekonomskih teškoća i prilagode na dobrobit djece mogla dodati i izravna poveznica između ekonomskog pritiska, odnosno ekonomskog stresa i dobrobiti djece, posebice djece u razvojnom razdoblju adolescencije.

\section{LITERATURA}

1/ AGNEW, R., MATTHEWS, S. K., BUCHER, J., WELCHER, A. N. I KEYES, C. (2008). "Socioeconomic status, economic problems, and delinquency". Youth \& Society, 40(2), 159-181.

2/ AJDUKOVIĆ, M. I RAJTER, M. (2014). „Obiteljski ekonomski stres kao čimbenik rizika za nasilne odgojne postupke i psihosocijalnu dobrobit djece“. U A. Brajša-Žganec, J. Lopižić i Z. Penezić (Ur.), Psihološki aspekti suvremene obitelji, braka i partnerstva (str. 353-375). Jastrebarsko: Naklada Slap i Hrvatsko psihološko društvo.

3/ BENNER, A. D. I KIM, S. Y. (2010). „Understanding Chinese American adolescents' developmental outcomes: Insights from the family stress model." Journal of Research on Adolescence, 20(1), 1-12. 
4/ BERK, L.E. (2008). Psihologija cjeloživotnog razvoja. Jastrebarsko: Naklada Slap.

5/ BOLGER, K. E., PATTERSON, C. J., THOMPSON, W. W. I KUPERSMIDT, J. B. (1995). „Psychosocial adjustment among children experiencing persistent and intermittent family economic hardship". Child Development, 66(4), 1107-1129.

6/ BRADLEY, R. H. I CORWYN, R. F. (2002). „Socioeconomic status and child development". Annual Review of Psychology, 53(1), 371-399.

7/ BRDOVČAK, B., MERKAŠ, M. I ŠAKIĆ VELIĆ, M. (2018). „Uloga nade i samopoštovanja u odnosu ekonomskog pritiska i zadovoljstva životom adolescenata“. Društvena istraživanja, 27(1), 87-108.

8/ CONGER, R. D., CONGER, K. J., ELDER, G. H., LORENZ, F. O., SIMONS, R. L. I WHITBECK, L. B. (1992). „A family process model of economic hardship and adjustment of early adolescent boys". Child Development, 63(3), 526 -541.

9/ CONGER, R. D., GE, X., ELDER, G. H., LORENZ, F. O. I SIMONS, R. L. (1994). „Economic stress, coercive family process, and developmental problems of adolescents". Child Development, 65(2), 541-561.

10/ CONGER, R. D., WALLACE, L. E., SUN, Y., SIMONS, R. L., MCLOYD, V. C. I BRODY, G. H. (2002). „Economic pressure in African American families: a replication and extension of the family stress model“. Developmental Psychology, 38(2), 179-193.

11/ CONGER, R. D., CONGER, K. J. I MARTIN, M. J. (2010). „Socioeconomic status, family processes, and individual development". Journal of Marriage and Family, 72(3), 685-704.

12/ DECARLO SANTIAGO, C., WADSWORTH, M. E. I STUMP, J. (2011). „Socioeconomic status, neighborhood disadvantage, and poverty-related stress: Prospective effects on psychological syndromes among diverse low-income families". Journal of Economic Psychology, 32(2), 218-230.

13/ ELDER Jr, G. H., CONGER, R. D., FOSTER, E. M. I ARDELT, M. (1992). „Families under economic pressure". Journal of Family Issues, 13(1), 5-37.

14/ EVANS, G. W. I ENGLISH, K. (2002). „The environment of poverty: Multiple stressor exposure, psychophysiological stress, and socioemotional adjustment". Child Development, 73(4), 1238-1248.

15/ LANDERS-POTTS, M. A., WICKRAMA, K. A. S., SIMONS, L. G., CUTRONA, C., GIBBONS, F. X., SIMONS, R. L. I CONGER, R. (2015). „An extension and moderational analysis of the family stress model focusing on African American adolescents". Family Relations, 64(2), 233-248.

16/ LEMPERS, J. D., CLARK-LEMPERS, D. I SIMONS, R. L. (1989). „Economic hardship, parenting, and distress in adolescence“. Child Development, 25-39. 
17/ MCLOYD, V. C. (1990). „The impact of economic hardship on Black families and children: Psychological distress, parenting, and socioemotional development". Child Development, 61(2), 311-346.

18/ MCLOYD, V. C. (1998). „Socioeconomic disadvantage and child development“. American Psychologist, 53(2), 185-204.

19/ MCLOYD, V. C., KAPLAN, R., PURTELL, K. M., BAGLEY, E., HARDAWAY, C. R. I SMALLS, C. (2009). „Poverty and socioeconomic disadvantage in adolescence“. U R. M. Lerner i L. Steinberg (Ur.), Handbook of adolescent psychology: Contextual influences on adolescent development (str. 444-491). Hoboken, NJ: John Wiley \& Sons.

20/ MISTRY, R. S., BENNER, A. D., TAN, C. S. I KIM, S. Y. (2009). „Family economic stress and academic well-being among Chinese-American youth: The influence of adolescents' perceptions of economic strain". Journal of Family Psychology, 23(3), 279-290.

21/ MISTRY, R. S., VANDEWATER, E. A., HUSTON, A. C. I MCLOYD, V. C. (2002). „Economic well-being and children's social adjustment: The role of family process in an ethnically diverse low-income sample". Child Development, 73(3), 935-951.

22/ MISTRY, R. S., LOWE, E. D., BENNER, A. D. I CHIEN, N. (2008). Expanding the family economic stress model: Insights from a mixed-methods approach. Journal of Marriage and Family, 70(1), 196-209.

23/ PARKE, R. D., COLTRANE, S., DUFFY, S., BURIEL, R., DENNIS, J., POWERS, J., FRENCH, S. I WIDAMAN, K. F. (2004). „Economic stress, parenting, and child adjustment in Mexican American and European American families". Child Development, 75(6), 1632-1656.

24/ PRAWITZ, A. D., KALKOWSKI, J. C. I COHART, J. (2013). „Responses to economic pressure by low-income families: Financial distress and hopefulness". Journal of Family and Economic Issues, 34(1), 29-40.

25/ RABOTEG-ŠARIĆ, Z., PEĆNIK, N. I JOSIPOVIĆ, V. (2003). Jednoroditeljske obitelji: osobni doživljaj i stavovi okoline. Zagreb: Državni zavod za zaštitu obitelji, materinstva i mladeži.

26/ RABOTEG-ŠARIĆ, Z., BRAJŠA-ŽGANEC, A. I ŠAKIĆ, M. (2009). „Life satisfaction in adolescents: The effects of perceived family economic status, self-esteem and quality of family and peer relationships". Društvena istraživanja, 18(3), 547-564.

27/ RABOTEG-ŠARIĆ, Z., MERKAŠ, M. I MAJIĆ, M. (2011). „Family characteristics, hope and optimism as determinants of academic achievement among adolescents". U D. Miljković i M. Rijavec (Ur.), Positive psychology in education: Book of selected papers (str. 73-88). Zagreb: Učiteljski fakultet Sveučilišta u Zagrebu. 
28/ RAJHVAJN BULAT, L. I AJDUKOVIĆ, M. (2012). „Obiteljske i psihosocijalne odrednice vršnjačkoga nasilja među mladima“. Psihologijske teme, 21(1), 167-194.

29/ RAJTER, M. (2013). Obiteljski stresori i obilježja obitelji kao prediktori roditeljskog nasilja nad djecom. (Neobjavljena doktorska disertacija). Pravni fakultet Sveučilišta u Zagrebu, Zagreb.

30/ ROSENBERG, M., SCHOOLER, C. I SCHOENBACH, C. (1989). „Self-esteem and adolescent problems: Modeling reciprocal effects". American Sociological Review, 54(6), 1004-1018.

31/ ROSENBERG, M. I PEARLIN, L. I. (1978). „Social class and self-esteem among children and adults". American Journal of Sociology, 84(1), 53-77.

32/ SELIGSON, J. L., HUEBNER, E. S. I VALOIS, R. F. (2003). „Preliminary validation of the Brief multidimensional students' life satisfaction scale (BMSLSS)“. Social Indicators Research, 61(2), 121-145.

33/ SHEK, D. T. (2003). „Economic stress, psychological well-being and problem behavior in Chinese adolescents with economic disadvantage". Journal of Youth and Adolescence, 32(4), 259-266.

34/ SHEK, D. T. (2005). „Economic stress, emotional quality of life, and problem behavior in Chinese adolescents with and without economic disadvantage". Social Indicators Research, 71(1-3), 363-383.

35/ SKINNER, M. L., ELDER, G. H. I CONGER, R. D. (1992). „Linking economic hardship to adolescent aggression". Journal of Youth and Adolescence, 21(3), 259-276.

36/ SNYDER, C. R., HOZA, B., PELHAM, W. E., RAPOFF, M., WARE, L., DANOVSKY, M., ... STAHL, K. J. (1997). „The development and validation of the Children's Hope Scale“. Journal of Pediatric Psychology, 22(3), 399-421.

37/ SOLANTAUS, T., LEINONEN, J. I PUNAMÄKI, R. L. (2004). „Children's mental health in times of economic recession: replication and extension of the family economic stress model in Finland“. Developmental Psychology, 40(3), 412-429.

38/ WADSWORTH, M. E. I COMPAS, B. E. (2002). „Coping with family conflict and economic strain: The adolescent perspective". Journal of Research on Adolescence, 12(2), 243-274.

39/ WADSWORTH, M. E., RAVIV, T., REINHARD, C., WOLFF, B., DECARLO SANTIAGO, C. I EINHORN, L. (2008). „An indirect effects model of the association between poverty and child functioning: The role of children's poverty-related stress". Journal of Loss and Trauma, 13(2-3), 156-185.

40/ YEUNG, W. J., LINVER, M. R. I BROOKS-GUNN, J. (2002). „How money matters for young children's development: Parental investment and family processes". Child Development, 73(6), 1861-1879. 
41/ YOSHIKAWA, H., ABER, J. L. I BEARDSLEE, W. R. (2012). „The effects of poverty on the mental, emotional, and behavioral health of children and youth: implications for prevention". American Psychologist, 67(4), 272-284.

\section{SAŽETAK \\ POVEZANOST EKONOMSKOG PRITISKA IZ PERSPEKTIVE RODITELJA I DJECE S DOBROBITI DJECE}

Svrha rada je ispitati povezanost dječjeg i roditeljskog doživljaja ekonomskog pritiska sa dobrobiti djece. U radu se empirijski provjerava u kojoj mjeri dječji doživljaj ekonomskog pritiska zajedno s roditeljskim doživljajem ekonomskog pritiska, uz kontrolu prihoda obitelji i obrazovanja roditelja, izravno pridonosi objašnjenju razine nade, samopoštovanja i zadovoljstva životom djece. Sudionici istraživanja bili su djeca i njihova oba roditelji koji su sudjelovali u kratkotrajnom longitudinalnom istraživanju s dvije točke mjerenja u okviru znanstvenog projekta „Rad roditelja, ekonomske teškoća obitelji i dobrobit roditelja i djece“. Djeca su procijenila ekonomski pritisak koji obitelj doživljava uslijed ekonomskih teškoća u prvom mjerenju te svoju razinu nade, samopoštovanja i zadovoljstva životom u drugom mjerenju. U prvom mjerenju, roditelji su procijenili ekonomskih pritisak koji osjećaju zbog uštede na troškovima za dijete te dali informacije o prihodu obitelji i svojem stupnju obrazovanja. Rezultati su pokazali da su dječji i roditeljski doživljaj ekonomskog pritiska značajno i pozitivno povezani te da su dječji i roditeljski doživljaj ekonomskog pritiska u prvom mjerenju značajno i negativno povezani s nadom, samopoštovanjem i zadovoljstvom životom djece u drugom mjerenju. Tri provedene regresijske analize, uz kontrolu prihoda obitelji i stupnja obrazovanja roditelja, pokazale su da je dječji doživljaj ekonomskog pritiska značajan i negativan prediktor nade, samopoštovanja i zadovoljstva životom u djece, dok se roditeljski doživljaj ekonomskog pritiska pokazao kao značajan i negativan prediktor zadovoljstva životom djece. Općenito, rezultati pokazuju da je doživljaj većeg ekonomskog pritiska u djece i roditelja povezan s nižom razinom dobrobiti djece u adolescenciji.

Ključne riječi: ekonomski pritisak; obitelji; adolescencija; dobrobit; longitudinalno istraživanje. 


\section{SUMMARY}

\section{THE RELATIONSHIP OF CHILDREN'S AND PARENTS' EXPERIENCE OF ECONOMIC PRESSURE WITH CHILDREN'S WELL-BEING}

The purpose of the paper is to examine the relationship between children's and parents' experiences of economic pressure and children's well-being. The paper empirically examines the extent to which children's experiences of economic pressure directly, along with parental experiences of economic pressure, and controlling for family income and parental education, contribute to the explanation of the level of hope, self-esteem, and life satisfaction in children. The participants in the study were children and both of their parents who participated in a short-term, two-wave longitudinal study within the scientific project "Parents' work, family economic hardship and well-being of parents and children". The children assessed the economic pressure that the family is experiencing due to economic hardship in the first measurement point, and their level of hope, self-esteem, and life satisfaction in the second measurement point. In the first measurement point, parents assessed the economic pressures they feel when they must reduce their child's expenses and provided information on family income and their educational level. The results showed that children's and parents' experiences of economic pressure were significantly and positively correlated, and that children's and parents' experiences of economic pressure measured in the first wave were significantly and negatively related with hope, self-esteem, and life satisfaction of children measured in the second wave. Three regression analyses, controlling for family income and parental education level, showed that children's experience of economic pressure was a significant and negative predictor of hope, self-esteem, and life satisfaction in children, while parental experience of economic pressure proved to be a significant and negative predictor of children's life satisfaction. In general, the results show that experience of higher economic pressure in children and parents is related with lower levels of well-being in children in adolescence.

Key Words: economic pressure; family; adolescence; well-being; longitudinal research. 
